\title{
What lies beneath: exploring links between asylum policy and hate crime in the UK *
}

\section{Abstract}

This paper explores the link between increasing incidents of hate crime and the asylum policy of successive British governments with its central emphasis on deterrence. The constant problematisation of asylum seekers in the media and political discourse ensures that 'anti-immigrant' prejudice becomes mainstreamed as a common-sense response. The victims are not only the asylum seekers hoping for a better life but democratic society itself with its inherent values of pluralism and tolerance debased and destabilised.

\section{Introduction}

In March 2010, three Russian asylum seekers from the same family leapt to their death from a block of rundown flats in Glasgow ${ }^{1}$. An earlier report by the Institute of Race Relations detailed many other cases of suicides and suspicious deaths of asylum seekers which may be, at least in part, attributable to the asylum process ${ }^{2}$. Such incidents are certainly not uncommon in Glasgow where asylum seekers have been dispersed to the most deprived areas of the city where aspirations are low and there is very little chance of integration into the host population. In 2004 , the charity Positive Action found that $75 \%$ of asylum seekers and refugees in the area had experienced violence and abuse ${ }^{3}$. Additionally, operational problems continue to beset the asylum process: from unnecessary delays and procedural errors to squalid housing to and destitution.

At the same time, a new racism based on cultural rather than biological superiority and the supposed ill-effects of other cultures on the white British heritage or English way of life is emerging ${ }^{4}$. Whereas the traditional forms of racism are today generally condemned (see for example the backlash to Nick Griffin's appearance on BBC's Question Time and the fact that the BNP has opened up its membership to non-whites ${ }^{5}$ ), a new form of xenophobia is tolerated and even encouraged in the pursuit of Britishness; an identity itself dependant on the fabrication of a mono-culture. Allegations of racism and discrimination are typically rejected

\footnotetext{
*Senior lecturer in law, Nottingham Law School, Nottingham Trent University. Nottingham NG1 4BU. I am most grateful to comments on earlier drafts from Dr Loretta Trickett and Dr Jonathan Doak both of Nottingham Law School.

${ }^{1}$ Harmit (2010).

${ }^{2}$ Institute of Race Relations (2006).

${ }^{3}$ The Daily Record (2004).

${ }^{4}$ Bowling and Phillips (2002).

${ }^{5}$ BBC (2009); Doward (2004).
} 
or downplayed with the consequence that it has becomes increasingly difficult to challenge discriminatory behaviour and inequality. As Van Dijk notes:

the white consensus that denies the prevalence of racism is a very powerful element in its reproduction, especially since resistance requires public attention, media coverage and at least partial recognition of grievances ${ }^{6}$.

There can be no informed public debate if the media and elected representatives are unwilling to move beyond the current discriminatory paradigm.

As the number of hate crimes increase, this paper will seek to explore whether racist violence and xenophobia more generally are being encouraged by policies which result in the criminalisation and destitution of asylum seekers. It will demonstrate how the use of inflammatory language in the media and political debates helps to fuel the perception that asylum seekers constitute a threat to the fabric of society. It will be argued that in the current economic crisis, asylum seekers have become perfect scapegoats lacking a political voice to challenge such misperceptions. Mistrust and suspicion becomes the de rigueur, common-sense response. Consequently the right to seek asylum is being eroded whilst the impression of the UK as a place of tolerance and sanctuary is exposed as an illusion. An examination of European asylum policy has become essential in this context, following the Amsterdam Treaty which brought certain aspects of immigration and asylum within the EU's legislative competence. Three significant directives have supported a common approach in refugee determination; reception conditions and, asylum returns. None take the right to seek asylum as a starting point; their objectives instead centre on reducing applications and burden-sharing. A lowest common-denominator approach pervades European asylum policy as European governments seek to show their electorates that they have immigration 'under control'. The construct of fortress Europe has emerged from ever increasing restrictions directed at outsiders with the effect that open and tolerant society is destabilised ${ }^{7}$.

Incidents of hate crime

The British Crime Survey estimated the number of racist incidents to be around 207,000 in the $2007 / 8$ period $^{8}$, a figure 150,000 more than the number of reported racist incidents. There is evidently chronic underreporting of hate crime. For asylum seekers this reluctance to report can partly be attributed to fear of the police and authorities due to their uncertain immigration

\footnotetext{
${ }^{6}$ Van Dijk $(1992,96)$

${ }^{7}$ Veenkamp et al (2003)

${ }^{8}$ British Crime Survey (2009).
} 
status but also to experiences of persecution in their country of origin ${ }^{9}$. Although the British Crime Survey does not provide specific details for the perceptions or incidents of crime among asylum seekers, it does demonstrate that ethnic minorities have a greater fear of crime than whites $^{10}$. This is corroborated by research undertaken by Refugee Action in 2002 which found that $83 \%$ of female refugees and asylum seekers surveyed did not go out at night for fear of harassment and crime ${ }^{11}$. Specialist police monitoring in London found that $30 \%$ of households reporting harassment were asylum seekers or refugees, a far greater proportion than were resident in the area ${ }^{12}$.

It has been noted that there have been particular problems with racist violence in Scotland, most notably Glasgow where many asylum seekers have been dispersed to sub-standard tower-block accommodation in impoverished areas of the city ${ }^{13}$. Police in the Lothian and Borders area which covers Edinburgh reported a huge increase in the number of reported racist crime in the year up to April 2008 with twice as many incidents as in the three years prior. A significant proportion of the victims were of Polish origin suggesting a different dimension to attacks which had in the past been predominately directed at black and Asian victims $^{14}$. The Scottish Executive noted that the stigma attached to asylum seeker and refugee status makes them increasingly vulnerable to victimisation and violence in the community ${ }^{15}$.

Notwithstanding the absence of precise data, it is officially acknowledged that asylum seekers and refugees suffer a disproportionate level of hate incidents and crimes ${ }^{16}$. The recently published Government Action Plan contains a long term vision which sings all the right notes, including a desire to promote an environment which discourages and condemns prejudices, hostilities, discrimination, portrayals and other factors that enable and cause hate crime ${ }^{17}$. Yet there is little detail to be found on the measures to be taken to advance this goal. For example, there is no consideration of measures that could be adopted to address hostile, inflammatory reporting in the media despite the findings of the Home Office's Community Cohesion report that the role of the media in undermining cohesion was constantly raised by respondents. The report also raised the same issues regarding political representatives and their tendency to make

\footnotetext{
${ }^{9}$ HM Government $(2009,9)$.

${ }^{10}$ Home Office (2007).

${ }^{11}$ Refugee Action (2002).

${ }^{12}$ ICAR (2004, 63).

13 Stewart (2007).

${ }^{14}$ Human Rights First (2008).

${ }^{15}$ Scottish Executive (2004, 5.39).

${ }^{16}$ HM Government $(2009,12)$.

${ }^{17}$ Ibid., 17.
} 
inflammatory statements undermining community cohesion ${ }^{18}$. Unsurprisingly the new hate crime strategy contains no discussion of the way that current asylum law and policy may encourage the demonization process. Findings from focus groups suggest that there is a direct causal effect between inaccurate, unbalanced media images of asylum seekers and negative, hostile views of the reader ${ }^{19}$.

The pattern of rising incidents of hate crime is replicated across Europe. Although many European states do not currently collate data on hate crimes, there has been a clear upward trend in racist crime in eight countries, including the UK, Germany and France over a six year period ${ }^{20}$. In 2009 the Organisation for Security and Cooperation in Europe adopted a decision endorsed by all 56 states to take important steps to combat hate crime ${ }^{21}$. But as with the national hate crime strategy, the decision addresses cure rather than prevention by committing states to compile statistics and to ensure better reporting and training for criminal justice officials. There is no mention of states committing their representatives to use less inflammatory language and to tackle widespread misconceptions regarding immigration and asylum.

\section{Defining Hate crime}

There is a considerable academic debate over the legitimacy of hate crimes laws which is beyond the scope of this paper, but it is worth emphasising the commonly advanced view that hate crime results in greater psychological harm than that which typically results from other crimes $^{22}$. Such crime impacts negatively on the whole target community, explaining why ethnic minorities have a greater fear of crime and additionally, they "impact on the shared values of equality held by the community as a whole"23. They are crimes against tolerance and diversity: crimes in essence against democracy.

Contemporary definitions of hate crime reflect the view of hate crime as a process directed at already stigmatised and marginalised groups. Barbara Perry's definition is particular pertinent in this context:

Hate crime involves acts of violence and intimidation usually directed towards already stigmatised and marginalised groups. As such, it is a mechanism of power and oppression intended to reaffirm the previous hierarchies that characterise a given social order. It attempts to re-create simultaneously the threatened ....hegemony of the

\footnotetext{
${ }^{18}$ Cantle $(2002,5.3 .2 ; 5.14)$.

19 ICAR $(2004,77)$.

${ }^{20}$ Human Rights First (2008b).

${ }^{21}$ OSCE (2009).

${ }^{22}$ See for example Iganksi (2002); Kahan (2001); Hurd (2001).

${ }^{23}$ Moon $(2002,555)$.
} 
perpetrator's group and the 'appropriate' subordinate identity of the victim's group. It is a means of marking both the Self and the Other in such a way as to re-establish their 'proper' relative positions, as given and reproduced by broader ideologies and patters of social and political inequality ${ }^{24}$.

The victim's perception of the motivation behind the incident is accepted by the Association of Chief Police Officers as the best way to attribute a hate or prejudice motivation ${ }^{25}$. The Crown Prosecution Service follows the same, broad approach and confirms that a victim may be targeted because of their perceived asylum seeker status alone ${ }^{26}$.However, the current method of statistical complication does not allow the victims' status or perceived status to be identified which makes it impossible to be certain of the number of people targeted for this reason Additionally, many hate incidents go unreported as victims' may regard such incidents as part of their daily life and, particularly if it is a pattern of recurring behaviour, may not wish to aggravate the situation by making a formal complaint. In areas of British National Party support there have reportedly been significant increases in racist incidents and victimisation ${ }^{27}$ with further evidence suggesting that there is a tendency to dismiss evidence of racist intention in many cases. Persons who are victims of hate crime may find themselves targeted repeatedly by what if often attributed to 'anti social' behaviour rather than criminal behaviour which is not seen as 'really offensive' but part of a trade in insults in the course of a neighbourhood dispute $^{28}$

The down-playing of racist intent by the police is related to the observation by many criminologists that perpetrators are often sanctioned by the wider community ${ }^{29}$. Accordingly, sympathizers draw on the wider culture including parents, teachers, friends and the media to support their hate ${ }^{30}$. One Home Office study on the perpetrators of racial harassment and violence found that tacit support by the wider community was commonplace:

The views held by all kinds of perpetrators towards ethnic minorities are shared by the wider communities to which they belong. Perpetrators see this as legitimising their actions. In turn, the wider community not only spawns such spectators, but fails to condemn them and actively reinforces their behaviour ${ }^{31}$.

\footnotetext{
${ }^{24}$ Perry $(2001,10)$.

${ }^{25}$ Hall $(1995,9)$; Bleich observes that the British definition is far more expansive than that used in Germany and France $(2007,151)$.

${ }^{26}$ Crown Prosecution Service (2010)

${ }^{27}$ Booth (2010).

${ }^{28}$ Ray and Smith $(2002,97)$.

${ }^{29}$ Levin (2002, 71-87).

30 ibid., 80.

31 Sibbitt (1997); see also Mason (2005).
} 
These findings are confirmed by a study in Greater Manchester which noted that typical perpetrators came from estates which were marginalised in all senses and where a sense of collective isolation pervaded $^{32}$. Commenting on the Northern disturbances of 2001, Dixon and Ray observed how fear and ignorance was fuelled by 'pernicious myth's' which divided communities by weakening social cohesion ${ }^{33}$. This 'enabling environment' is supported by and conditioned by the activity or inactivity of the state ${ }^{34}$. These 'pernicious myths' routinely see asylum seekers portrayed as economic migrants and/or criminals ${ }^{35}$. They become perfect scapegoats; distracting people from real, underlying concerns such as unemployment and poverty and real insecurity about the future ${ }^{36}$. There is limited political will to challenge these myths as it would necessitate a genuine engagement with the complexities of the real issues. People find scapegoats to blame for their situation and this scape-goating then appears legitimised by the inaction of community leaders and ultimately the political elite $^{37}$.

Whilst these enabling factors form the backdrop to perceptions of otherness, specific causative factors also need to be considered if we are to identify the conditions which result in perpetrators deciding to act on their perceptions.

\section{Causative factors}

The dramatic pace of socio-economic change in British society has widened the gap between affluent and poor communities. Competition for resources and dependence on welfare provides fertile ground for xenophobia ${ }^{38}$. In many cases support from the wider community legitimises and encourages violence towards foreigners. Marginalised gangs may begin as social outcasts but once they direct their frustration towards asylum seekers or immigrants their status appears to change favourably as they begin to obtain the respect that they have craved. On top of the individual factors, polarised political situations and inflammatory media reporting in which immigration policy is commonly depicted as a problem provide fertile ground for the emergence of violence ${ }^{39}$. Frost observes how existing structural factors such as environmental disadvantage are compounded by additional factors that facilitate racial prejudice:

Two such examples are the role played by dominant cultural and political discourses as disseminated by government policy, and by the negative reporting of immigration by

\footnotetext{
${ }^{32}$ Ray et al (2003, 119).

${ }^{33}$ Dixon and Ray $(2007,115)$.

${ }^{34}$ Perry $(2001,179)$.

${ }^{35}$ Ottewell (2007).

${ }^{36}$ Sibbitt.(1987).

${ }^{37}$ Association of London Authorities (1993).

${ }^{38}$ Hopkins Burke and Pollock $(2004,11)$.

| ${ }^{39}$ Bjorgo and Witte $(1993,43)$.
} 
sections of the media...the existence of broader socio-economic and political conditions that combine with a hostile media and government stance can facilitate racism and the particular complexion this takes ${ }^{40}$.

The influence of political rhetoric and leadership is thus of paramount importance to understanding the normalisation of hatred.

\section{The influence of political rhetoric}

Political rhetoric and media sensationalism play large parts in problematising asylum seekers and refugees. Political polarisation often results in immigration being seen as a hot topic. In the UK, political parties regularly battle over which has the strongest, most restrictive policies on immigration. The question of asylum is typically lost within this battle and subsumed into the general immigration debate.

Opinion polls have consistently revealed the public perception that immigration and asylum policies are 'not tough enough' and that the 'problem of asylum is out of control'. In one particular YouGov survey for the Daily Mail in 2004, 11\% of the public agreed strongly (and 26\% tended to agree) with the proposition that 'a significant proportion of asylum seekers in Britain are terrorists' ${ }^{41}$. More recently, the Independent Asylum Commission's 'Citizens Speak' consultation found the majority of respondents were critical of the asylum system and in particular asylum seekers, who were seen as receiving special, preferential treatment and benefits ${ }^{42}$. Interestingly, the Commission also found that many of the same respondents were in favour of providing sanctuary to those fearing persecution but that they had received the message that most applicants were actually bogus ${ }^{43}$. The statistics show that the number of asylum seekers coming to the UK has been decreasing fairly steadily since the peak in 2001 with $48 \%$ fewer applications in the first quarter of 2010 compared to the same period of the previous year. Despite the initial recognition rate of only $15 \%$, over half the applicants are eventually recognised as needing protection with $27 \%$ of applications accepted on appeal and $10 \%$ receiving discretionary or humanitarian leave $\mathrm{e}^{44}$. This picture is seldom presented to the public during political debate and it rarely features in popular news stories.

Capdevilla and Callaghan have examined the opposition speeches of MP Michael Howard in 2005 which locate the need for tighter immigration controls within a context of

\footnotetext{
${ }^{40}$ Frost $(2007,238)$.

${ }^{41}$ YouGov (2003; 2004); see also YouGov Survey for Commission for Racial equality: Racial equality 2004: http://www.youcov.co.uk/corporate/archives/press-archives-social-Main.asp?dID=2005.

42 Independent Asylum Commission (IAC 2008, 4).

43 Ibid.

${ }^{44}$ Home Office (2010).
} 
cleaner hospitals and more police; thus equating immigration with both a lack of cleanliness and criminality ${ }^{45}$. His speeches describe an asylum system which is out of control. Most disturbing is the alleged link between terrorism and asylum:

We face a real terrorist threat in Britain today - a threat to our way of life, to our liberties...there is a quarter of a million failed asylum seekers living in our country today. No-one knows who they are or where they are. To defeat the terrorist threat we need action not talk - action to secure our borders ${ }^{46}$.

The irony of course is that that the perpetrators of terrorist attacks in British soil have predominately been British citizens - born and bred in this climate of tolerance. Whilst the speech clearly equates asylum with criminality and terrorism, it also alludes to an idealized vision of 'British-ness' which is threatened by these outsiders. The link between immigration and criminality can be seen more recently in the Labour party's 2010 manifesto entitled 'A future fair for all' in which an entire section on strengthening communities is devoted to 'Crime and Immigration ${ }^{47}$.Howard does not feel it necessary to substantiate the link between asylum and terrorism as it is presented as axiomatic. But in keeping with the desire to disassociate from accusations of racism, he is at pains to confirm that he is not a racist by referring to his own ancestry as a descendant of Russian Jews ${ }^{48}$. More recently, the 'dangerous game' of allowing gay asylum seekers to claim asylum in the United Kingdom has been highlighted by Conservative MP Philip Davies ${ }^{49}$. The Supreme Court's judgement that Gay men in Cameroon and Iran may experience persecution on account of their sexuality was also described as 'absurd' by former MP Anne Widdecombe who predicted that civil unrest may result from such decisions ${ }^{50}$. The former Labour minister responsible for immigration and asylum, Phil Woolas, angered immigration activists shortly after he took up his post by emphasising that most asylum seekers were economic migrants and accusing immigration lawyers of undermining the law in their support for unworthy appeals ${ }^{51}$. Yet many asylum seekers struggle to find any legal representation; a position made much worse by the recent closure of the UK's largest specialist legal representation charity in the immigration field. Refugee Migrant Justice went into administration in June 2010 due to financial difficulties which they laid squarely at the door of the Government ${ }^{52}$.

\footnotetext{
${ }^{45}$ Capdevila and Callaghan $(2008,5)$.

${ }^{46}$ Extract from Michael Howard's conference speech 2005 cited in Ibid., 5.

${ }^{47}$ Labour Party Manifesto (2010). Available at Labour.org.uk.

${ }^{48}$ Capdevilla and Callaghan $(2008,97)$.

${ }^{49}$ Daily Express (2010)

${ }^{50}$ Widdecombe (2010).

51 Telegraph (2008).

${ }^{52}$ New Statesman (2010).
} 
The link between political rhetoric and violence is a common theme in criminological research. Regular use of terms such as 'bogus' in political debates on immigration and asylum are seldom substantiated by evidence ${ }^{53}$. The constant problematization of asylum seekers can only serve to reinforce the impression that the asylum system is out of control. Fifteen years ago, the Association of London Authorities demanded that more attention was focussed on the underlying factors which breed, excuse or support racist activity ${ }^{54}$. In this context, the Home Office's Racial Attacks Group noted the obligation on politicians and those with influence on public opinion to avoid encouraging feelings of racial antipathy "politicians at both local and national level obviously have a crucial role to play in helping to create a cohesive and tolerant society" ${ }^{\prime \prime 5}$.

The use of openly inflammatory language in contemporary political debate appears to have declined but at the same time there has been a discernible shift to less obvious, pejorative labels, including metaphors such as swamping and flooding. The European Commission on Racial Intolerance and Xenophobia have suggested that negative perceptions by the media and politicians are poisoning public opinion and that they are being translated into increasingly restrictive policies and legislation, such as that contained in the Draft Immigration Bill 2009 which makes it an offence for an asylum seeker to knowingly enter without a valid travel document $^{56}$. Such charges have also been levied at political debate in Germany and Sweden where immigration restrictions appeared to legitimise the arguments of the anti-immigration lobby ${ }^{57}$. The effect of restrictionism in the UK will be explored later in this paper.

\section{Media influences}

The media are of course vital in helping shape public perception of social and political issues particularly on immigration where the experience of most white Britons is very limited ${ }^{58}$. Yet the picture painted is complex and misleading. Research by the Article 19 project at the University of Cardiff found 51 different labels used by the media to define asylum applicants

\footnotetext{
${ }^{53}$ Spencer $(1998,81)$.

${ }^{54}$ Sibbitt $(1987,85)$.

55 Ibid., 85.

${ }^{56}$ ECRI (2009, para.175). Clause 301 Draft Immigration Bill 2009.

${ }^{57}$ Karapin $(1999,437)$.

${ }^{58}$ Bailey and Harindranath (1993, 282); Van Dijk (1993, 243).
} 
including 'asylum cheat' and 'illegal refugee ${ }^{59}$. Typically the most popular daily newspapers play on public anxieties by depicting Britain as a country under siege from welfare dependant asylum applicants $^{60}$. A further common theme is the implied link between asylum seekers and criminality $^{61}$. Consequently asylum seekers themselves feel alienated and ashamed by their negative portrayal in the British media ${ }^{62}$.

Fear is understandably generated in communities by stories of "waves of refugees" ${ }^{63}$ or to learn that the asylum system is "engulfed in chaos" 64 . Analysing the media response to the murder of a Kurdish asylum seeker in Glasgow, Carolyn Coole found that coverage "helped to create a climate of opinion in which readers were invited to view the incomers as a threat". Rather that counteracting misperceptions about asylum seekers the typical media response was to fuel ethic tension by labelling the attack as racially motivated and depicting the local community as unable to cope with the dispersed asylum seekers ${ }^{65}$.

One project examining the impact of the media on community relations in London, found that almost half of the photographs of asylum seekers or refugees in national newspapers presented them as criminals. Other pejorative photographs included images of the Union jack being shown in association with asylum stories suggesting a challenge to traditional

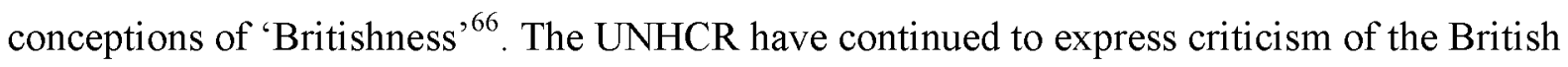
press in this regard ${ }^{67}$. Yet the label 'asylum cheat' continues to feature regularly in headlines found in many daily newspapers ${ }^{68}$.

This negative depiction creates a contagion effect where anti-immigration activists are buoyed by media accounts of similar actions in other regions. Bjorgo observes that in many cases isolated, personal disputes were erroneously defined as part of a race-war by the media which escalated disputes as in the Glasgow incident ${ }^{69}$. This contagion effect has also been noted in the context of German hate crime ${ }^{70}$. Again, there is a sense that anger towards foreigners, including asylum seekers becomes normalised ${ }^{71}$.

\footnotetext{
${ }^{59}$ Article 19 Project. Available at: www. 19.org/pdfs/publications/refugees-what-s-the-story-case-study-pdf. These findings are also demonstrated in research over 6 months in 2007 by Wurie Khan (2008).

${ }^{60}$ Spencer $(1998,81)$.

${ }^{61} \operatorname{ICAR}(2004,35)$.

${ }^{62}$ Article 19 Project. Available at: www. 19.org/pdfs/publications/refugees-what-s-the-story-case-study-pdf.

${ }_{63}^{63}$ Bjorgo (1993, 105).

${ }^{64}$ Daily Express (2009).

${ }^{65}$ Coole (2002); see also Grillo(2005).

${ }^{66}$ ICAR (2004, 28 and 29).

${ }^{67}$ UNHCR (2006, 10-11).

${ }^{68}$ See for example Daily Mail $(2002 ; 2010)$.

${ }^{69}$ Bjorgo (1993, 103).

${ }^{70}$ Green et al $(2001,496)$.

${ }^{71}$ ibid., 489.
} 
It is submitted that anti-asylum and anti-foreigner rhetoric often escapes critical attention and is somehow regarded as 'fair comment'. Research on media responses to asylum during the early to mid 1990's (a period during which many asylum applicants from the ethnic conflict in Yugoslavia, arrived in the UK), found that The Daily Mail used the expression 'bogus' in $90 \%$ of articles concerning asylum seekers ${ }^{72}$. The Press Complaints Commission subsequently issued guidance to the media emphasising that inaccurate, misleading or distorted reporting may generate an atmosphere of fear and hostility that is not borne out by the facts' and 'there can be no such thing in law as an 'illegal asylum seeker" ${ }^{\text {,73 }}$. In August 2001 Daily Express journalists passed a motion "expressing disapproval at the sustained campaign against asylum seekers in pursuit of circulation" having made a complaint to the Press Complaints Commission regarding editorial pressure to produce inflammatory stories. A subsequent complaint was made in 2004 regarding pressure to produce anti-Gypsy articles ${ }^{74}$. Following the recent Supreme Court decision there has been protests outside the Daily Express offices about the newspaper's unsympathetic, inflammatory coverage ${ }^{75}$.

Whilst such guidance has had some effect on the way that the national press label asylum applicants, there remains confusion over what these labels actually mean. There has also been a tendency in both printed and broadcast media to give a platform to organisations which represent a particular anti-immigration agenda without actually clarifying the agenda to readers and listeners. In the UK, Sir Andrew Green is head of the anti-immigration think tank, Migration Watch UK. He presents his organisation as a neutral, research orientated advisory body and is regularly cited in news reports as if he is an independent expert without any counterbalancing view being offered ${ }^{76}$

The construction of difference through binary oppositioning whereby the Other is presented in a simplistic, negative comparative framework, is recognised by Hall ${ }^{77}$; the identity of 'Us' can be shored up and strengthened through a positive comparison with 'Them'. Bailey and Harindranath argue that the media has a tendency to use binary oppositioning to simplify highly complex situations and relationships ${ }^{78}$. In the case of asylum seekers, they are presented as 'foreign' in a paradigm of territorial sovereignty which challenges the traditional, including the home and the family. The repeated use of the term bogus or illegal asylum

\footnotetext{
${ }^{72}$ Kaye $(2001,58)$.

73 The Press Complaints Commission (2003).

${ }^{74}$ Press Gazette (2004).

${ }^{75}$ The Guardian (2010).

${ }^{76}$ Wetherell $(2003,19)$.

${ }^{77}$ Hall ( 1995,237$)$.

${ }^{78}$ Bailey and Harindranath $(1993,277)$.
} 
seekers is commonplace in this paradigm. War also becomes a particularly useful metaphor, for example: 'new weaponry in the armoury of immigration services' which suggests that 'we' are fighting a war on asylum ${ }^{79}$.The asylum applicant is thus stereotyped as a threat and their real life story is ignored or denied to support this interpretation.

This process of Othering allows us to exclude those so labelled from our concern ${ }^{80}$. Whilst this is typically not a conscious process, the use of war metaphors and the association of asylum with criminality promotes and legitimises this view. Banks explores the visual representation of asylum seekers and refugees showing how newspaper imagery constructs such groups as dangerous and deviant. Building on a deviancy amplification model, he has identified three stages in the discovery of deviance that collectively demonstrate how the social portrayal of the criminal immigrant fuses the otherness of the stranger with the otherness of the deviant. In the first phase, the faceless and de-identified stranger enables the construction of a panoply of feared subjects. Stigma is then implicitly illustrated, deviance obliquely intimated and 'spoiled identities' are constructed. ${ }^{81}$ The mask is then removed and the asylum seeker is revealed with their deviant status confirmed. He then demonstrates how such a process is reinvented, repeated and reworked in news stories, with deviance becoming increasingly engrained and entrenched in the image of the asylum seeker ${ }^{82}$. The views of criminologists are supported by the results of psychological tests on stereotyping which found that exposing viewers to negative media stories linking asylum seekers with criminality resulted in negative judgements ${ }^{83}$. Consequently, when the study group were asked to consider the merits of asylum applications they became more likely to refuse the application.

One of the common problems in the depiction of asylum seekers in the press has been a blurring of labels such as immigrant, asylum seeker and refugee. Often the terms are used interchangeably which suggests erroneously that there is no obvious distinction between a person entering the UK under immigration laws and those seeking asylum. Inaccurate labelling serves a useful political purpose as the motivation of people entering the country is lost and the implication is that they intend to occupy an illegal space in society. Exclusion strategies thus become easy to justify as a defence against the hostile invader ${ }^{84}$. Again the absence of real life stories is critical to the success of this discourse as exclusion would be so much more difficult to justify if asylum seekers were presented as being the same as everyone else. Saxton defines

\footnotetext{
${ }^{79}$ ibid., 281.

${ }^{80}$ Greenwald and Krieger (2006, 946); Stabile (2009).

${ }^{81}$ Goffman (1963, passim).

${ }^{82}$ Banks (2009).

${ }^{83}$ Lido et al (2006).

${ }^{84}$ Saxton $(2003,113)$.
} 
this as a "sanitised racist discourse that functions to establish, sustain and reinforce oppressive power relations between the dominant group and racial minorities" ${ }^{\prime 25}$.

The policy of deterrence

In addition to political rhetoric and media sensationalism, the law has been far from neutral ${ }^{86}$. Law helps to legitimise the perception of 'them' as it exercises both an expressive and pedagogic role ${ }^{87}$. The message of the legal provisions on asylum is clear: asylum seekers are not welcome. The use of detention and the prohibition on work mean that for many people asylum seekers are inherently criminals and/or economic burdens. Their experiences of persecution cannot be imagined by the host society and it thus becomes easy to regard them as unequal and undeserving.

Legislation on immigration and asylum is frequently introduced with a preamble of 'fair but firm' yet the perception that immigration is out of control remains (despite falling numbers of asylum applicants $)^{88}$. Politicians appear to manipulate the debate by playing on peoples' fears for electoral advantage with loopholes highlighted in stories of alleged abuse of the system. Consequently "negative language has become the currency of public discourse on immigrants and asylum seekers" ${ }^{\prime \prime 9}$.

The 'fair but firm' agenda suggests that there is no alternative but to take a strict line on refugee determinations. Van Dijk notes the routine combination of fairness on one hand with pragmatism, realism and firmness in the parliamentary debates of several liberal states ${ }^{90}$. In this way the humanitarian objective can be diluted by some vague, pragmatic sense of a greater good. The argument suggests that there is no rational alternative to the view that strong immigration controls are a requirement for good community cohesion. Both sides of the political spectrum seem to have carelessly absorbed this view. Having defeated the BNP leader Nick Griffin in the general election, the Labour member of parliament, Margaret Hodge, felt the need to suggest that rationing housing by prioritising long term residents might be a solution to the popularity of the far-right ${ }^{91}$. The irony of this strategy is not lost on Simon Goodman:

\footnotetext{
${ }^{85}$ ibid., at 118 .

${ }^{86}$ Tuitt (1996).

${ }^{87}$ Stabile $(2009,21)$.

${ }^{88}$ Coleman (1996).

${ }^{89}$ Spencer $(1998,91)$.

${ }^{90}$ Van Dijk (1992, 110-111).

${ }^{91}$ Harris (2010).
} 
It relies on the threat posed by extremist parties, and their more harsh policies on asylum seekers, to justify a move towards a position that more closely reflects the position of these extremists. In short, the argument here is that we must be more like the BNP to stop the BNP from gaining political success ${ }^{92}$.

There is no middle-ground in this form of analysis. It is unclear why asylum seekers are either to be placed in detention or luxury accommodation. Rather than 'firm but fair' this debate has placed 'firmness' and 'fairness' at polar opposites with firm policies becoming the norm in the last two decades with reductions in welfare support, expansion of the detention estate and increased penalties for unauthorised entry. There is an irreconcilable tension between increasing the focus on hate crimes and such regressive steps where the asylum seeker is defined as bogus, illegitimate and threatening ${ }^{93}$.

Dehumanization is an essential consequence of the rationalisation of hate towards 'out groups'. The challenge therefore is for policy to address the construction of 'out' groups but, in the case of asylum seekers, there has been a notable reluctance to do this. Even those MP's that are concerned about the treatment of asylum seekers tend to avoid being engaged publically on the subject, perceiving that it is not a vote winner to be exposed as 'soft' on immigration. There is also a view among many politicians that the only way to stop the extreme Right "has been to steal their electoral clothes, by taking a hard-line approach to immigration and asylum"

An examination of the law providing for the detention of asylum seekers is particularly illuminating in the context of this debate. As in other cases where liberty is restricted, one may expect to see requirements of necessity and proportionality at the forefront of the legal criteria Yet, the law provides no maximum time limit for the detention of asylum seekers and successive Governments have expanded the detention estate makes it increasingly common for asylum seekers to experience detention without any requirement of necessity.

\section{Detention}

The UK has the largest number of people detained under immigration laws in Europe with a capacity to detain 30,000 people ${ }^{95}$. State practices vary enormously with some countries, including Britain, the Netherlands and Denmark avoiding a legal commitment to a maximum detention period. Increasingly states are resorting to detention for administrative convenience with the emphasis again being on 'firmness'. In the case of Saadi v UK [2008] ${ }^{96}$, the European

\footnotetext{
${ }^{92}$ Goodman $(2008,120)$

${ }^{93}$ Gadd $(2004,145)$.

${ }^{94} \operatorname{IRR}(2010,2)$

95 Travis $(2010)$.

${ }^{96}$ Saadi v UK (2008).
} 
Court of Human Rights endorsed this use of detention for short periods as falling within the exception to the right to liberty found in Article 5 (1) $\mathrm{f}^{97}$. As a result, the designated removal centre at Oakington now detains asylum seekers for up to fourteen days with no requirement for the Home Office to show 'necessity' such as a risk of absconding or it being pursuant to imminent removal.

The qualification on the right to liberty for asylum seekers is not seen in other contexts. In criminal justice and mental health detention, where the exceptions to Article 5 have been narrowly construed, the European Court of Human Rights has emphasised that effective and regular judicial supervision are key requirements of detention. In Brogan $v U K^{98}$, the detention of terrorism suspects for periods of four and seven days was held to breach the requirement for suspects to be bought promptly before a judicial authority ${ }^{99}$. It is also clear that there must be reasonable grounds for suspicion before a person can be detained or arrested. Similarly if a person of 'unsound mind' is to be detained there must be a medical assessment of necessity to ascertain that the person is suffering from a mental illness ${ }^{100}$. In Litwa v Poland ${ }^{101}$ the need to consider all alternatives prior to detaining a person under Article 5(1) e was emphasised with the court stressing that it but must also be necessary in the circumstances ${ }^{102}$.

Thus we see a different standard of liberty applied in the immigration and asylum context. This may itself be a reflection of the European Court's concern to avoid making decisions which impact on the territorial integrity of states. The Convention itself makes no specific mention of a right to seek asylum or enter a particular state, unlike the Universal Declaration on Human Rights which provides in Article 14, the right to seek and enjoy asylum. However, it is less clear why such factors should not be construed in the context of the states margin of appreciation rather than being built into the framework of Article 5.

According to international law and the Home Office's operational enforcement manual, detention should not be considered appropriate where there is evidence of torture. Yet evidence recently uncovered shows that detention is not unusual in these cases ${ }^{103}$. The charity Care of Victims of Torture collated figures over an eighteen month period, revealing that only 7 out of 250 detainees had been released following evidence of torture ${ }^{104}$. Issues of poor health care

\footnotetext{
${ }^{97}$ O'Nions (2008).

${ }^{98}$ Brogan v UK (1989).

${ }^{99}$ Article 5(3) ECHR.

${ }^{100}$ Cornelisse $(2004,105)$.

${ }^{101}$ Litwa v Poland (.2000)

${ }^{102}$ Ibid., para 78.

${ }^{103}$ Townsend (2010).

${ }^{104}$ Ibid.,
} 
have been raised on numerous occasions by professional bodies ${ }^{105}$ with a recent academic report finding evidence of an 'institutional failure to address health concerns about asylum seekers in detention ${ }^{\prime 106}$. The detention of children has also attracted widespread condemnation from international and domestic organisations who have been concerned about the effects of detaining vulnerable children ${ }^{107}$. In 2009 it was estimated that up to 1000 children are placed in immigration detention in the UK each year with the average period of detention being over fourteen days ${ }^{108}$. One of the first policy changes of the new coalition Government has seen a welcome pledge to end all such detention of children but the difficulties of determining age and the broader issue of detaining vulnerable people are left unresolved.

The UK's desire to detain asylum seekers has received criticism from the European Commission Against Racism and Intolerance which noted a link between Government policies such as destitution, poor decision making and detention, and the hostile tone of public discourse ${ }^{109}$. Again, there was specific recognition of the exploitation of racism in politics and the media which were highlighted as particular causes for concern ${ }^{110}$. The routine use of detention inevitably links asylum seekers with criminality in the public perception. It can certainly be seen to fuel the perception that there is something wrong or dangerous with those seeking sanctuary and in this way it surely contributes to animosity towards asylum seekers as a whole ${ }^{111}$. Welch and Schuster identify it as an essential element in the state ritual of firm immigration policies:

"That penal ceremony has become a media theatre on whose stage politicians proclaim their intentions to clamp-down on so-called bogus asylum seekers fraudulently in search of welfare, benefits, education, health-care, housing and jobs".

\section{Work and benefits policies}

Another aspect of current asylum policy which deserves attention in this context is the current rule denying asylum seekers permission to work in the UK whilst their application is being determined. Since July 2002 work and vocational training is not permitted until a positive decision has been received or the applicant has been waiting for an initial decision for over a

\footnotetext{
${ }^{105}$ Ginn (2009).

${ }^{106}$ Verkaik (2010).

107 The Children's Commissioner (2010).

${ }^{108}$ House of Commons, Home Affairs Committee (2009).

${ }^{109}$ ECRI $(2010,8)$.

${ }^{110}$ Id., at 9 .

${ }^{111}$ Sales $(2002,459)$.
} 
year (delayed appeals are not counted in this calculation) ${ }^{112}$. This particular rule needs to be seen in the light of wider immigration entry conditions such as the 'no recourse to public funds' rule.

Asylum applicants can apply for some support and accommodation to the UK Borders Agency but the latter will be subject to the dispersal programme. Accommodation is offered to those considered destitute by a mixture of providers and the applicant is permitted no choice in the location. Consequently a disproportionate number of asylum seekers become homeless or dependant on over-stretched charitable provision ${ }^{113}$. The dispersal cluster system also means that many specialist services that would have been available in the larger cities are no longer accessible for those who need them ${ }^{114}$. Once an asylum claim is rejected the applicant and their family will be expected to take steps to leave the UK and may continue to receive support until the children reach $18^{115}$. However, the family will be denied this support under $\mathrm{s} 9$ Asylum and Immigration (Treatment of Claimants) Act 2004 if they are considered not to have taken reasonable steps to depart voluntarily. The consequences of this provision for the welfare of children in vulnerable familial circumstances cannot be overstated ${ }^{116}$.

Again the 'them' and 'us' relationship is emphasised as the policy draws a boundary between the 'deserving' and 'undeserving' in society ${ }^{117}$. The denial of the right to work has helped to label asylum seekers as 'undeserving' and as burdens (hence, threats) to the economic stability of the state.

The workplace could constitute an opportunity for asylum seekers to interact with the host population in a positive, shared setting but this opportunity has been missed and opportunity for positive interaction is minimal. When interaction is forced upon communities, as happens with dispersal initiatives which appear to be poorly thought out and under-resourced, asylum seekers inevitably become caught up in social disintegration and poverty. Denial of the right to work inevitably means greater reliance on state support. However, state support itself will be unavailable unless the asylum application falls with s55 Nationality Immigration and Asylum Act 2002 which specifically excludes claimants that do not apply as soon as reasonably practicable after arrival. In $R v S S H D \exp$ Adan, Limbuela, Tesema [2005] the Home Secretary attempted to argue that the policy should prevail even in

\footnotetext{
${ }^{112}$ Current rules can be found at: http://www.ukba.homeoffice.gov.uk/asylum/support/employment/

${ }^{113}$ Homelessness Link (2000).

${ }^{114} \mathrm{~A}$ review of the literature is provided by Aspinall and Watters $(2010,102)$.

${ }^{115}$ s95 Immigration and Asylum Act 1999.

${ }^{116}$ Aspinall and Watters $(2010,71)$.

${ }^{117}$ Sales (20020).
} 
cases where the applicant was left destitute and homeless as a consequence of it's operation ${ }^{118}$. The House of Lords however, determined that there had been a breach of Article 3 of the European Convention on Human Rights as the applicants had suffered inhuman and degrading treatment as a consequence of the policy's operation. S55 remains on the statute books however as a key element of the deterrence strategy. This is notwithstanding the Home Office's own research suggesting that the timing of an asylum application has little bearing on the legitimacy of the applicant's case ${ }^{119}$.

A related issue which adversely affects many vulnerable asylum seekers is the policy withdrawing free medical treatment from certain groups including failed asylum seekers unable to travel home and undocumented migrants. A recent Court of Appeal decision confirmed that failed asylum seekers are not 'ordinarily resident' in the UK and therefore are not entitled to secondary NHS treatment ${ }^{120}$. A consultation process is currently underway which proposes specific exemptions for secondary healthcare for failed asylum seekers who are cooperating with the UK Border Agency and are supported under s4 or s95 ${ }^{121}$. S4 cases concern adults who are taking reasonable steps to leave but there is a genuine recognised barrier to them leaving and $\mathrm{s} 95$ provides support to the estimated 7,600 failed asylum seekers who would otherwise be considered destitute ${ }^{122}$. At present neither of these groups receive free secondary healthcare.

Lessons can be learnt from Barbara Perry's seminal work on the demonization of Black Americans. She demonstrates how the mother who is dependant on welfare support is perceived to be morally responsible for factors beyond her control including the disintegration of family values and the American way of life, and the economic woes of the country ${ }^{123}$. Politicians are then shown to play on these stereotypes for their own popularity with disastrous consequences for inter-racial relations. In the UK the asylum seeker fits this stereotype in a way which would be difficult to apply to the black community of modern Britain. Family values are depicted as threatened by young, male asylum seekers who are considered to be economic migrants and who, on successful application, may then ask for their extended families to join them ${ }^{124}$.

\footnotetext{
${ }^{118}$ UK HL 66.

${ }^{119}$ O'Nions (2006).

${ }^{120}$ A v SS for Health [2009] EWCA Civ 225.

${ }^{121}$ Asylum (Treatment of Claimants) Act 2004 and Immigration and Asylum Act 1999 respectively.

${ }^{122}$ Aspinall and Watters (2010).

${ }^{123}$ Perry $(2001,183)$.

${ }^{124}$ See for example the printed opinions following "A depressingly predictable attack on asylum seekers" The Independent $30^{\text {th }}$ July 2009.
} 
The operation of the dispersal programme means that asylum seekers are typically directed to poor, deprived areas where there is already generalised violence and casual racism. The particular problems experienced by those in Glasgow demonstrate the relationship between poverty, deprivation, social exclusion and a general culture of violence which is often directed at those perceived to be outsiders.

Conversely, migrants from EU member states, that are exercising their right to work, are also perceived as a threat, particularly as they are accused of taking the jobs of British workers. It is no coincidence that the legally questionable promise of 'British jobs for British workers' made by Gordon Brown to the TUC in 2007 was subsequently adopted as party slogan for the far-right British National Party ${ }^{125}$. One of the more balanced daily newspapers, The Independent, talked of a "crackdown' on migrant workers" following the prime-ministers comments; clearly apportioning blame for jobs shortages in the British economy to the migrants who were legally exercising rights conferred by European law ${ }^{126}$. This is a point also noted in Perry's analysis of the United States: "From this perspective, immigrants- especially Third World immigrants- come to this country for two reasons: to sack the welfare system and to take the jobs of the Americans" 127 .

\section{The overall effect of the deterrence agenda on public perception}

Despite falling numbers of applications, asylum policy remains focussed on preventing asylum seekers from exercising their right to seek asylum as guaranteed by the Universal Declaration of Human rights ${ }^{128}$. Formal mechanisms such as introduction of visa requirements, reduction of welfare support, criminal penalties for carriers of clandestine passengers are clear examples of this objective. Consequentially asylum seekers are typically misunderstood by the British public and in some cases this has yielded violent reactions. It might even be contended that these reactions are another element in the deterrence strategy; something that Perry would describe as an 'informal mechanism of control', 129 .

If deterrence is the objective of asylum policy these measures do seem to be having some success with a dramatic reduction in the number of people seeking asylum since the peak

\footnotetext{
${ }^{125}$ Summers (2009).

${ }^{126}$ Russell (2007).

${ }^{127}$ Perry (2001, 197).

${ }^{128}$ As provided in Article 14 Universal Declaration of Human Rights 1948, UN; O'Nions (2006).

${ }^{129}$ Perry $(2001,79)$.
} 
in $2002^{130}$. There are many on the political right who would be comforted by this outcome but we need to consider why successive Governments have become so obsessed with asylum to the extent that the United Kingdom can no longer be seen, in the time-honoured tradition, as a place of sanctuary. We need to further consider the consequences of this obsession for settled refugees and the wider community of ethnic minorities in the UK. If we see hate crimes, intolerance and support for far right policies as indicators of disunity which threaten the fabric of our democracy, there is at present much cause for concern across Europe. Contrary to the populist view that strong immigration controls promote positive race relations ${ }^{131}$ there is evidence to support the opposite contention; our obsession with deterring asylum seekers from seeking sanctuary is in fact damaging race relations. The problematization of asylum seekers cannot be seen in any other way ${ }^{132}$. The prevalence of myths which are not countered by politicians inevitably leads to community tension as evidenced in the so-called 'Northern disturbances' of 2001 and the Birmingham 'race riots' of $2005^{133}$.

\section{European policy}

As European law and policy advance well beyond the original objectives of the Treaty of Rome, an ideological construction of the true European has emerged ${ }^{134}$. It is contended that this true European is defined primarily by its relationship with non-European 'others'.

Rising numbers of hate crime incidents are recognised in a recent Council framework decision yet the decision makes no reference to recent EU asylum policies as evidenced, for example, in the Returns directive which restricts access to the European club ${ }^{135}$. As the EU has opened up to new members the problem of how to close it to 'Others' has become a focal point $^{136}$. The Council of Europe has recently added its voice to concerns over the hardening of attitudes towards immigrants and asylum seekers in Europe and the proliferation of detention ${ }^{137}$. The Parliamentary Assembly's resolution expresses particular concern over the detention of asylum seekers and includes ten principles of guidance including requirements of proportionality and necessity. More specifically, fifteen rules are delineated. It is submitted

\footnotetext{
${ }^{130}$ The peak was 84,130 in 2002 which declined dramatically to 23,610 in 2006 . The most recent statistics suggest that the level has stabilised with 29,800 fresh applications in 2009: UNHCR Asylum Levels and trends in industrialized countries in 2009: statistical overview UNHCR $23^{\text {rd }}$ March 2010.

${ }^{131}$ This has been a regular feature of Conservative party election manifestos: Dale $(2000: 254,302,388,452)$

${ }^{132}$ Spencer (1998, 82).

${ }^{133}$ Dixon and Ray $(2007,117)$.

${ }^{134}$ Anthias et al $(1993,131)$.

${ }^{135}$ European Council (2008); (2008b).

${ }^{136}$ Cited in Dummett (1998, 211).

${ }^{137}$ Parliamentary Assembly (2010).
} 
that many European states do not at present comply with these rules which include: effective access to the outside world; legal advice, assistance and representation of the highest quality; appropriate material conditions of detention and effectively trained detention centre staff. The detention of asylum seekers is clearly viewed as arising in exceptional circumstances only after a full consideration of alternatives.

In this area of asylum policy, the relative positions of the Council of Europe and the European Union are certainly not harmonious. The latter's Returns directive has been dubbed the 'directive of shame' in Latin America. It adopts a lowest common denominator or 'minimum standards' approach in which detention of up to 18 months is permissible ${ }^{138}$. Amnesty International and the European Council on Refugees and Exile had urged the European Parliament to reject the plans but the directive was eventually approved despite some reservations from parliamentarians ${ }^{\prime 139}$. The text also includes periods of custody and re-entry bans for up to five years and establishes a common discipline for all member states to either expel every illegally resident migrant or grant him/her a definite legal status. The detention of children and families is not specifically prohibited and unaccompanied minors will 'only be repatriated' if they can be returned to their families or to "adequate reception facilities". Despite its restrictive nature, the Home Office have requested an opt-out from the new directive due to concern that the current fast-track detention and removal procedure for manifestly unfounded cases could be deemed unlawful ${ }^{140}$. Further concern was expressed that the provisions would require states to provide legal aid and improved translation services.

More generally, there are warning signs that race relations may deteriorate further in Europe as the results from recent general and European elections reveal a rise in the mainstream popularity of far-right political parties such as the British National Party, the Swiss Peoples Party, the Danish Peoples Party and the fascist Northern League and National Alliance in Italy. All of these parties have strong anti-immigrant platforms but few are openly racist in the traditional sense. Xenophobia is typically presented as a reasonable response to economic decline and the perceived loss of identity.

\footnotetext{
${ }^{138}$ Venezuelan President Hugo Chavez called the rules "shameful" and threatened both to cancel investment in and disrupt oil exports to the countries that enact the controversial immigration measures. While Brazilian President Lula da Silva said "the cold winds of xenophobia are once again blowing from Europe," his Ecuadorean colleague Rafael Correa warned that trade talks between the EU and the Andean Community could be suspended if the 27 member bloc pushed ahead with the new law. "What do we have to talk about with a union of countries that criminalises immigrants? It will be very hard to talk business and ignore human rights." Cited on Euractiv News (2008).

${ }^{139}$ ECRE (2008); Administrator (2008).

${ }^{140}$ Travis (2010a).
} 
An additional threat is paradoxically posed by attempts to reinvigorate democracy in Europe. The Lisbon treaty contains provisions to revitalise European democracy including the European Citizen's initiative which requires the Commission to respond to collective petitions with one-million intra-state signatories ${ }^{141}$. The danger of majoritarian politics dictating the agenda are illustrated by the experience in Switzerland where referenda are commonplace. The referendum in Sjobo on providing shelter to refugees resulted in $67 \%$ of residents voting against the proposals ${ }^{142}$. Local referenda on similar issues with similar results have also been reported in France and Sweden and highly organised local campaigns against asylum seekers have been reported in Ireland and the Netherlands. Many of these campaigns are influenced by the far-right. Playing on the typical stereotypes, Jean-Marie Le Pen has recently called for a national referendum in France to curb immigration which, he described as a "burden on France's lifestyle, its finances, its security, its unemployment and schools" ${ }^{\prime 143}$. It would be a grave mistake however, to see the far right as the only influence in such campaigns. As I have shown, mainstream political debate on immigration and asylum typically centres on the view that strong immigration controls are necessary for positive race relations. The nature of these strong controls is rarely identified, but there is certainly no attempt to separate issues of immigration and asylum or to correct underlying assumptions that the majority of those entering the UK (from the EU and beyond) are unwelcome. The Institute of Race Relations has argued that the debate on reinvigorating democracy has seen insufficient attention paid to the relationship between direct democracy and human rights or between majoritarian politics and the situation of minorities and disenfranchised groups ${ }^{144}$.

\section{Conclusion}

Asylum seekers and refugees are increasingly the targets of hate incidents. The strategy of deterrence has helped to create a culture of suspicion and disbelief which has permeated public opinion $^{145}$. The use of detention and the tendency for politicians to link asylum with criminality helps to legitimise this culture and encourages intolerance ${ }^{146}$.

The emphasis on a traditional British mono culture which is the basis of BNP policy is not being significantly refuted by politicians from the main parties. As Spencer argues 'The

\footnotetext{
${ }^{141}$ European Parliament (2010).

${ }^{142}$ Reported in Institute of Race Relations Briefing (2010, 2).

${ }^{143}$ Agence France Presse (2010).

${ }^{144}$ Institute of Race Relations $(2010,2)$.

${ }^{145}$ Frost $(2007,240)$.

${ }^{146}$ Cohen (2003).
} 
UK needs to update it self image to accommodate its multicultural diversity ${ }^{147}$. As government appears to be the "primary influence on public opinion" there needs to be a real attempt to counter such prejudice by the political elite. This cannot be done in a climate of overly restrictive asylum policies which criminalise and dehumanise asylum seekers.

Asylum and immigration are not synonymous. Yet they are conflated in much of current political discourse and media stories where asylum seekers are pushed together with other migrants as people whose presence is unwelcome ${ }^{148}$. Current law and policy underpin this position. At the same time, xenophobic rhetoric directed at asylum seekers is taken out of the traditional understanding of racism, posing new challenges for labels such as 'hate crime' and for racism itself. The law fuels this hate by lumping all asylum seekers and other migrants together as 'unwanted commodities' and in doing so it takes anti-asylum seeker rhetoric outside the typical understanding and language of racism posing problems for concepts such as 'hate crime' and 'racism'.

The promotion of democracy and tolerance require that society recognise the changing face of racism. Crimes perpetrated against asylum seekers are justified by the same arguments as other forms of racism. They result from the same misinformation, frustration and fear. At the same time they appear to be more socially acceptable; finding support from much of the British media and our elected representatives.

A balanced public debate has been resisted yet is urgently required so that the need for international protection is understood and respected ${ }^{149}$. The effects of positive media coverage can be dramatic ${ }^{150}$. Intolerance can be challenged by a responsible political debate and balanced media reportage which must include the airing of 'real life stories'. As we 'lower the voices of some to hear the voices of others' we can begin to appreciate the real experiences of asylum seekers including the level of open discrimination that is typically part of their daily lives $^{151}$. A process of a sentimental education could serve to challenge the media tendency to demonise asylum seekers and the liberalist tendency to 'empty' asylum applicants of their diverse experiences in order to categorise and define the legitimate refuge ${ }^{152}$. There is much that could be done, but whilst a tough stance on immigration is perceived by many to be a vote winner, asylum seekers are caught in an impossible position. As Frost contends:

\footnotetext{
${ }^{147}$ Spencer (1998, 91).

${ }^{148}$ Hayter (2000).

${ }^{149}$ House of Commons $(2009,179)$.

${ }^{150}$ Refugee Action (2006); Wurie Khan (2008).

${ }^{151}$ Fiss (1996).

${ }^{152}$ Parker, and Brassett $(2005,236)$.
} 
Both government and sections of the media have been pivotal in casting asylum seekers (alongside Muslims) as the new 'folk devils' of British society by criminalising these as 'bogus' economic migrants, as welfare scroungers, terrorists, disease carriers and 'illegals'. Their alleged high and increasing numbers and alleged refusal to 'integrate' represent asylum seekers as undesirables who threaten the cultural integrity of Britain $^{153}$.

Xeno-racism is one way to forge a British identity in a time of economic instability and societal insecurity. Asylum seekers, lacking a political voice, have become the easiest target in the search for scapegoats ${ }^{154}$. It would take a brave politician indeed to counter the common-sense sentiment that has been fuelled by twenty years of increasingly restrictive asylum policy ${ }^{155}$.

The campaign to punish hate crime is praised as a 'radical intervention' by Iganksi who perceives it as promoting justice "by attempting to mould the collective conscience" 156 . It is now time to mould that collective conscience again, by acknowledging the effects of current asylum policy on the hate debate and on race relations in the United Kingdom.

Word count: 9689 (exc bibliography).

\footnotetext{
${ }^{153}$ Frost $(1997,243)$.

${ }^{154}$ Fekete (2009); Karapin (1998, 216).

${ }^{155}$ Iganksi $(2008,29)$ observes how this common-sense racism developed in the context of anti-semitism.

${ }^{156}$ Ibid., 94.
} 


\section{BIBLIOGRAPHY}

A v SS for Health [2009] EWCA Civ 225.

Administrator. (2008) "Europe: No asylum, now go to jail" Crime and Justice International, Houston:

Sam Houston State University.

Agence France Presse. (2010) $6^{\text {th }}$ January 2010.

Anthias,F; Yoval-Davis, N and Cain, H. (1993) Racialized Boundaries. London: Routledge.

Association of London Authorities. (1993) Racial abuse: An everyday experience for some Londoners.

Submission to the House of Commons Home Affairs Committee Inquiry into Racially-motivated

Attacks and Harassment London: Association of London Authorities.

Article 19 Project. (2003) Univ. of Cardiff. Available at:

http://www.cardiff.ac.uk/jomec/research/researchgroups/racerepresentationandculturalidentity/funded projects/article 19project.html (accessed 14.7.10).

Aspinall, P and Watters, C. (2010) Refugees and Asylum seekers. A Review from an Equality and Human Rights Perspective. Manchester: Equality and Human Rights Commission.

Bailey, OG and Harindranath, R. (2005) "Racialised 'othering" in Allen, S (ed.) Journalism: Critical Issues. London: Open University Press pp274-286.

Banks, J (2009). 'Unmasking Deviance: The Visual Construction of Asylum Seekers and Refugees', The European Society of Criminology Conference, Univ. of Ljubljana, Slovenia Bleich, E (2007). "Hate crime policy in Western Europe" Vol. 51 (2): 151 American Behavioural Scientist.

Crown Prosecution Service. (2010) Racist and Religious Crime-CPS Prosecution Policy London: CPS. Booth, R .(2010) "Rise in hate crime follows BNP Council election victories" The Guardian $15^{\text {th }}$ Jan. Bowling, B and Phillips, C. (2002) Racism, Crime and Justice. Harlow: Longman.

BBC. (2009) Question Time $22^{\text {nd }}$ Oct.

Bjorgo, T. (1993) "Role of the media in racist violence" in Bjorgo and Witte (eds.) Racist Violence in Europe. Basingstoke: Palgrave 96 - 112.

Bjorgo, T. (1993) "Terrorist Violence against immigrants and Refugees in Scandinavia: Patters and Motives" in Bjorgo and Witte (es.) Racist Violence in Europe. Palgrave: Basingstoke 29-46.

Bjorgo, T and Witte, R. (1993) Racist Violence in Europe. Palgrave: Basingstoke.

Boskin, J. (1980) "Denials: the media view of dark skins and the city" in Rubin (ed) Small Voices and Great Trumpets: Minorities and the Media. New York: Praeger 141-147.

British Crime Survey. (2009) Crime in England and Wales 2008-2009. London: Home Office Statistical Bulletin.

Brogan v UK (1989) 11 EHRR 117

Cantle, T. (2002) Community Cohesion: A report of the Independent review. London: Home Office. Capdevila, R and Callaghan, J . (2008) "It's not racist. It's common sense" Journal of Community and Applied Social Psychology. 18: 1-16. 
Children's Commissioner. (2010)The Arrest and Detention of Children subject to Immigration Control. London: The Children's Commissioner.

Cohen, S. (2003) No One is Illegal Stoke-on-Trent: Trentham Books.

Coleman, D. (1996) “UK immigration policy: 'firm but fair' and failing?” Policy Studies. 17

(3): $195-214$

Coole, C. (2002) "A warm welcome? Scottish and UK media reporting of an asylum seeker murder" Media, Culture and Society. 24 (6): 839-849.

Cornelisse, G. (2004) "Human rights for immigration detainees in Strasbourg: limited sovereignty or a limited discourse?" EJML.6: 93-110.

Daily Express "Now asylum if you're gay" $7^{\text {th }}$ July 2010

Daily Express (2009) "Asylum system engulfed in chaos" $16^{\text {th }}$ June 2009.

Daily Mail (2002) "ID cards lead war on asylum cheats" $1^{\text {st }}$ July.

Daily Mail (2010) "Iraqi asylum cheat" $26^{\text {th }}$ June.

Daily Record. (2004) "Surge in race hate" March $9^{\text {th }}$.

Dale, I (2000), Conservative Party General Manifesto's 1900-1997.London: Routledge.

Dixon, L and Ray, L. (2007), "Current issues and developments in race hate crime" Probation Journal. The Journal of Community and Criminal Justice. 45 (2)109-124.

Doward, (2004) "BNP to allow Black recruits" The Observer, August $1^{\text {st }}$.

Dummett, A. (1998) "British Race Relations in a European context" in Blackstone, Parekh and Sanders (eds.) Race Relations in Britain: a Developing Agenda. London: Routledge 204-220.

ECRE. 'European Council for Refugees and Exiles' Press release (2008) "Returns Directive: European Parliament and Member States risk compromising respect for migrants' rights" $20^{\text {th }}$ May 2000.

European Commission Against Racism and Intolerance. (2010) Report on the United Kingdom. CRI (2010) 4 Strasbourg: Council of Europe.

ECRI European Commission against Racism and Intolerance Report on the United Kingdom CRI (2010)4.(Strasbourg: Council of Europe, 2010) $2^{\text {nd }}$ March.

EuroActiv News $29^{\text {th }}$ January 2008 and response of $27^{\text {th }}$ June 2008. Available at:

http://www.euractiv.com/en/socialeurope/spain-explains-directive-shame-latin-america/article-17372 $\underline{7}$ (accessed on 11.12.10)

European Council. (2008) The Council's Framework decision on Combating certain forms and Expressions of Racism and Xenophobia by Means of Criminal Law. Council of the EU Brussels $26^{\text {th }}$ Feb 2008 16771/07.

European Council. (2008b) Common Standards and Procedures in Member States for Returning Illegally Staying Third-country Nationals. $18^{\text {th }}$ June 2008.

European Parliament. (2010) Regulation of the European Parliament and Council on the Citizens' Initiative 2010/0074 (COD) Brussels, $31^{\text {st }}$ March.

Fekete, L. (2009) A Suitable Enemy. London: Institute of Race Relations. 
Fiss, O. (1996) The Irony of Free Speech. Mass: Harvard Univ. Press.

Frost, D. (2007) “The 'enemy within'? Asylum, racial violence and 'race hate' in Britain today" $21^{\text {st }}$ Century Society. 2(3):227-248.

Gadd, D; Dixon, B and Jefferson, T. (2005) Why do they do it? Racial harassment in North Staffordshire: Key Findings Keele: ESRC and Centre for Criminological research, Univ. of Keele . Gadd, D. (2004) "Hate and bias crime: Criminologically congruent law? A review of Barbara Perry's Hate and Bias Crime: A reader" The Australian and New Zealand Journal of Criminology 37(1): 144-154.

Ginn, E. (2009) "Intercollegiate Briefing paper: Significant harm - the effects of administrative detention on the health of children, young people and their families" Royal College of General Practitioners, Royal College of Paediatrics and Children's Health, Royal College of Pyschiatrists and the UK faculty of Public Health. Available at:

http://www.medicaljustice.org.uk/images/stories/texts/significant $\% 20$ harm $\% 20$ intercollegiate $\% 20$ stat ement $\% 20 \mathrm{dec} 09$.pdf. (accessed 14.7.10)

Goffman, E.(1963) Stigma: notes on the Management of spoiled Identity New Jersey: Prentice Hall.. Goodman, S. (2008) "Justifying harsh treatment of asylum seekers through the support of social cohesion" Annual Review of Critical Psychology 6: 110-124 .

Green, McFalls and Smith. (2001) "Hate crime: an emergent research agenda" Annual Review of Sociology 27: 494

Greenwald, A and Krieger, LH. (2006) "Implicit bias: Scientific Foundations" 945 CAL L REV 945.

Grillo, R. (2005) "Saldtean can't cope' protests against asylum-seekers in an English seaside suburb" Ethnic and Racial Studies. 28 (2): 235-260.

The Guardian "Protests over 'gay asylum' coverage" $15^{\text {th }}$ July 2010.

Hall, N. (1995) Hate Crime. Abingdon: Willan Publishing.

Harmit, A. (2010), "Protests follow deaths in Glasgow" London: Institute of Race Relations News, $11^{\text {th }}$ March.

Harris, J. (2010) “Labour's new motto: immigration, immigration, immigration" The Guardian. 22 May.

Hayter, T. (2000), The Case Against Immigration Controls. London: Pluto.

HM Government. (2009) Hate Crime-Cross Government Action Plan. London: HMSO. Available at: http://library.npia.police.uk/docs/homeoffice/hate-crime-action-plan.pdf (accessed 14.7.10)

Home Office .(2010) Control of Immigration. Quarterly Statistical Summary. May 2010 London:

Home Office.

Home Office. (2007) Attitudes, Perceptions and risks of crime: Supplementary Volume 1 to Crime in England and Wales 2006/7 19/0729 $9^{\text {th }}$ Nov London: Home Office. 
Homelessness Link. (2000) Homelessness Amongst Migrant Groups. March. Available at: www.homless.org.uk/migration-project.

Hopkins Burke, R and Pollock, E. (2004) "A tale of two anomies: some observations on the contribution of (sociological) criminological theory to explaining hate crime motivation" Internet Journal of Criminology.

House of Commons, Home Affairs Committee .(2009) The Detention of Children in the Immigration System. 2009-2000 $24^{\text {th }}$ Nov. (2009) HC 73 London: HMSO.

Human Rights First (2008a) "2008 Hate Crime Survey: Racism and Xenophobia" New York: Human Rights First.

Human Rights First. (2008b) Violence based on Racism and Xenophobia. New York: Human Rights First.

Hurd, H. (2001) "Hate crime legislation" Law and Philosophy. 20 (1): 215-232.

ICAR. (2004) Information Centre about Asylum Seekers and Refugees Media Image, Community Impact. April. Kings College, London: Information Centre on Asylum seekers and Refugees.

Iganksi, P. (2008) Hate Crime and the City. Bristol: Policy Press.

Iganksi, P. (ed) (2002) The Hate Debate. Institute for Jewish Policy Research: Profile Books. Independent Asylum Commission .(2008) Saving Sanctuary: The Independent Asylum Commissions' first report of Conclusions and recommendations. London: IAC.

IRR (2010) Institute of Race Relations European Race audit "Direct democracy racism and the extreme right" Briefing paper No2 Feb 2010.

IRR (2006) 'Institute of Race Relations’ Driven to Desperate Measures Institute of Race Relations Jacobs, J and Potter, K. (1998) Hate Crimes. Criminal law and identity Politics OUP: New York. Kahan, D. (2001)“Two liberal fallacies in the hate crimes debate" Vol. 20, 2 Law and Philosophy 20(2):175-193.

Karapin, R. (1999) "The politics of migration control in Britain and Germany: subnational politicians and social movements" Comparative Politics 31(4) 423-44.

Karapin, R (1998), "Radical-right and neo-fascist political parties in Western Europe" Comparative Politics. 30 (2) 213-234.

Kaye, R. (2001) "Blaming the victim. An analysis of press representation of refugees and asylum-seekers in the UK in the 1990's" Media and Migration 53-69 .

Labour Party. Manifesto (2010) A Future Fair For All. Available at Labour.org.uk.

Levin, J. (2002) "Hatemongers, dabblers, sympathizers and spectators: a typology of offenders" in Iganksi, P. (ed) The Hate Debate. Institute for Jewish Policy Research: Profile Books 71-87. Lido, C; R. Calitri, R; Samson, A and Brown, R. (2006), "Effects of the media priming positive and negative asylum-seeker stereotypes on thoughts and behaviours" ESRC funded Project, Res 000 $-22-0773$.

Litwa v Poland (2000) App No 26629/95 4.4.2000. 
Mason, G. (2005) "Hate crime and the image of the stranger" British Journal of Criminology. 45 (6): 837-859.

Moon, G. (2002) "The hate debate: should hate be punished as a crime?" EHRLR. 4: 555-556.

New Statesman (2010) "Refugee and Migrant Justice placed into Administration" New Statesman15th June 2010.

O'Nions, H. (2008) "No right to liberty: the detention of asylum seekers for administrative convenience" European Journal of Migration and the Law. 10(2): 149-185.

O'Nions, H.(2006) "The erosion of the right to seek asylum" 2 Web JCLI..

OSCE (2009) Decision No 9/09 Combating Hate Crimes Athens:OSCE.

Ottewell, D. (2007) "MP to slam asylum policy" Manchester Evening News. June $13^{\text {th }}$

Parker, O and Brassett, J. (2005) "Contingent borders, ambiguous ethics: migrants in (international) political theory" International Studies Quarterly. 49:233-253.

Parliamentary Assembly. (2010) On detention of asylum seekers and irregular migrants in Europe Res $1708(2010)$.

Perry, B. (2001) In the Name of Hate New York: Routledge.

Press Complaints Commission. (2003) Code of Practice http://www.pcc.org.

Press Gazette (2004) "Express staff call in PCC over anti-Gypsy articles" 30" January 2004.

Ray, Smith and Wastell. (2003) "Understanding Racist violence" in Stanko (ed) The Meanings of Violence NY: Routledge 112- 129.

Ray, L and Smith, D. (2002) "Hate crime, violence and cultures of racism" (2002) in Iganski, P. (ed)

The Hate Debate. Institute for Jewish Policy Research: Profile Books 88-102.

Refugee Action. (2002) Is it Safe Here? London: Refugee Action.

Russell, B. (2007) “Jobs for Every Briton' says Brown in crackdown on Migrant workers'” Monday $10^{\text {th }}$ Sept The Independent.

Refugee Action. (2006) News Release "Plymouth refugees tell the truth about asylum" $20^{\text {th }}$ Oct 2006 London: Refugee Action.

Saadi v UK (2008) App 13229/03, Grand Chamber of the European Court of Human Rights Judgment of $29^{\text {th }}$ January 2008.

Sanders (eds.) Race Relations in Britain. A Developing agenda London: Routledge 74-95.

Saxton, A. (2003). "I certainly don't want people like that here: the discursive construction of asylum seekers" Media International Australia 109-120.

Scottish Executive. (2004). "Working group on hate crime" Edinburgh: Scottish Executive.

Sibbitt, R. (1997) The Perpetrators of Racial Harassment and Racial Violence Home Office Research Study 176 London: Home Office.

Spencer, S. (1998) "The impact of immigration policy on race relations" in Blackstone, Parekh and Stabile, S. (2009) 'Othering' and the law" Univ. of St Thomas Legal Studies Research paper No 08-37. Stewart, S. (2007) “Asylum seekers targeted by gangs” BBC News March $2^{\text {nd }}$. 
Summers, D. (2009), "Brown stands for British Jobs for British workers" January $30^{\text {th }}$ Guardian Unlimited.

Telegraph (2008) "Phil Woolas accuses asylum seeker lawyers and charities of 'playing the system"” The Telegraph $18^{\text {th }}$ Nov. 2008

Townsend, M. (2010) "UK Ignoring evidence of torture among asylum seekers" $14^{\text {th }}$ March The Observer.

Travis, A. (2010a) "Home Office to opt out of asylum claims EU directive" $24^{\text {th }}$ Feb. Guardian Unlimited

Travis, A. (2010b) "UK detention centre to double capacity" $26^{\text {th }}$ May The Guardian.

Tuitt, P. (1996) The Law's Construction of the Refugee. London: Pluto.

UNHCR. (2010) Asylum Levels and trends in industrialized countries in 2009: statistical overview.

UHHCR. Available at:

http://www.unhcr.org.uk/news-and-views/news-list/news-detail/article/number-of-asylum-seekers-re mains-stable-over-2009-unhcr-figures-show.html (last accessed 11.12.10)

UNHCR $23^{\text {rd }}$ March 2010. Available at: http://www.unhcr.org/4ba734la9.html (last accessed 11.12.10).

UNHCR (2006) "Asylum "Madness" in the UK" Refugees 142 (1): 10-11

Van Dijk, TA. (1993) Elite Discourses and Racism. London: Sage.

Van Dijk, TA. (1992) "Discourse and the denial of racism" Discourse and Society. 3: 87-118.

Veenkamp, T. Bentley, T and A. Buonfino. (2003) People Flow London: Demos.

Verkaik, R. (2010) "Refugees 'denied vital health care services" $9^{\text {th }}$ March The Independent.

Verkaik, R. (2004) "Race hate crimes reach record levels - and experts say asylum policy may be to blame" $7^{\text {th }}$ April The Independent .

Welch and Shuster. (2005) "Detention of asylum seekers in the UK and USA" Punishment and Society. 7 (4): 397-417.

Wetherell, M. (2003) "Racism and the analysis of cultural resources in interviews" in Vanden Berg, H; Wetherell, M and Houtkoop-Steenstra, H (eds.) Analyzing Race Talk: Multidisciplinary Approaches to the Interview. Cambridge Univ. Press 11-30.

Wurie Khan, A. (2008) 'Countering media hegemony, negative representations, the 'bad citizen': asylum seekers' battle for the hearts and minds of Scotland" Social Engagement, Empowerment and Change. 11.

YouGov (2003) Surveys for The Sun 2003; for The Daily Mail December 2004; YouGov survey for Commission for Racial equality: Racial Equality 2004. Available at: http://www.youcov.co.uk/corportae/archives/press-archives-social-Main.asp?dID=2005. 
